\title{
PENGEMBANGAN SISTEM INFORMASI MANAJEMEN PENGELOLAAN KEARSIPAN DI LEMBAGA JAMINAN SOSIAL
}

\author{
Dhea Perdana Coenraad ${ }^{1}$, Imam Heryanto ${ }^{2}$, Haris Nurdiansyah ${ }^{3}$, Jimmy \\ Rusjiana $^{4}$ \\ Sekolah Tinggi Ilmu Ekonomi Pasundan, Bandung $1,2,3,4$ \\ Email: dhea@stiepas.ac.id', imam@stiepas.ac.id ${ }^{2}$, haris@stiepas.ac.id ${ }^{3}$, \\ jimmy@stiepas.ac.id ${ }^{4}$
}

\begin{abstract}
This study aims to see to what extent the effectiveness of an information system that has just been implemented in a social security institution where this system is a replacement for the previous system which is considered less effective in managing archives. Based on the results of research and testing, it was found that this new system has a better effectiveness value and a far more optimal level of accuracy in archiving management.
\end{abstract}

Keywords: information systems, archives, social security institutions.

\begin{abstract}
Abstrak
Penelitian Penelitian ini memiliki tujuan untuk melihat sejauh mana efektifitas sebuah system informasi yang baru diterapkan disebuah Lembaga jaminan social dimana system ini merupakan pengganti dari system sebelumnya yang dianggap kurang efektif dalam pengelolaan kearsipan. Berdasarkan hasil penelitian dan pengujian didapatkan hasil bahwa system yang baru ini memiliki nilai efektiftitas yang lebih baik dan tingkat keakuratan pengelolaan kearsipan yang jauh lebih optimal.
\end{abstract}

Kata Kunci: sistem informasi, kearsipan, lembaga jaminan social. 
April, 2021

\section{PENDAHULUAN}

Pengelolaan arsip merupakan sesuatu hal yang sangat penting dalam sebuah organisasi. Arsip adalah bukti dan rekaman kegiatan atau transaksi mulai dari awal sampai akhir kegiatan yang berhubungan dengan pengambilan keputusan. (Eveleigh, 2017) Arsip dapat digunakan baik untuk keperluan penggunaan data dan informasi internal maupun untuk eksternal organisasi. (Feng, 2017) Salah satu informasi yang sangat penting bagi suatu organisasi adalah rekaman dari kegiatan organisasi itu sendiri. Rekaman tersebut terdapat pada arsip. (Barros, de Toledo Carneiro \& Wanderley, 2019)

Arsip belum dianggap sebagai hal penting dalam kehidupan berbangsa dan bernegara. Buktinya, hal ini terbukti dengan banyaknya arsip milik negara yang hilang, aset negara yang raib karena tidak adanya dukungan dokumen arsip, sulit menemukan kembali arsip dengan cepat dan tepat di sebuah organisasi, penumpukan arsip disembarang tempat, dan pengelolaan arsip yang sembarangan. Menurut Kepala Arsip Nasional Republik Indonesia (ANRI) Mustari Irawan "Permasalahan arsip di negara kitaIndonesia sedemikian kompleks sehingga perlu adanya pengelolaan. Padahal arsip perlu dikelola dengan baik mengingat ini adalah sebuah catatan penting," kata Kepala Arsip Nasional Republik Indonesia (ANRI) Mustari Irawan. Hasil pembinaan kearsipan yang dilakukan ANRI melalui kegiatan pengawasan dan evaluasi menunjukkan hanya sebagian kecil dari $179 \mathrm{~K} / \mathrm{L}$ atau kementrian dan lembaga, 167 perguruan tinggi negeri, 146 badan usaha milik negara (BUMN), 34 pemerintah daerah provinsi, dan 514 kabupaten/kota, yang mengelola arsipnya dengan baik.

Sebagai suatu lembaga yang bergerak dalam hal asuransi Sosial, Lembaga Jaminan Sosial dihadapkan pada banyaknya arsip yang perlu dikelola setiap hari, bulan dan bahkan setiap tahunnya. Penulis mencatat tidak kurang dari 20 lembar dokumen yang masuk atau keluar setiap harinya pada satu unit kerja di Lembaga Jaminan Sosial, dimana dokumen tersebut berhubungan dengan data, catatan, dan atau keterangan terkait pengelolaan jaminan atau kegiatan operasional lembaga. Diperlukan upaya dan penanganan khusus terhadap arsip arsip tersebut agar dalam penggunaannya menjadi lebih mudah, terstruktur dan cepat dapat diakses kembali saat diperlukan.

Kondisi yang terjadi saat ini masih belum menunjukkan adanya penataan yang baik dimana saat ini arsip lebih banyak dibukukan dalam bentuk file yang tersimpan dan tersusun pada lemari-lemari dan flying cabinet sehingga tidak menutup kemungkinan sewaktu-waktu dapat menimbulkan masalah ketika arsip tersebut dibutuhkan seperti akses kembali yang membutuhkan waktu yang cukup lama karena arsip tertumpuk dan juga perlu adanya bagian khusus yang menangani hal tersebut. Tidak jarang penulis melihat petugas kerepotan mengurus 
April, 2021

arsip yang masuk dan keluar sehingga kerap kali memakan waktu yang lama ketika ada klaim dari pihak tertentu yang membutuhkan mengakses kembali datadata kearsipan tersebut.

Pengelolaan kearsipan pada Lembaga Jaminan Sosial seyogyanya sudah cukup baik namun seiring berkembangnya teknologi maka perlu ada pembenahan dan upaya baru dalam memudahkan pengarsipan yang dilakukan sehingga memberikan kemudahan dalam penyimpanan dan pengaksesan kembali sehingga kegiatan kerasipan ini dapat berjalan dengan lebih baik dan terkontrol secara jelas dan nyata. Kemajuan teknologi menuntut organisasi untuk serba cepat dan praktis dalam melaksanakan tugas dan fungsinya tidak terkecuali dalam hal pengarsipan dimana saat ini organisasi dituntut untuk mampu melayani dengan waktu yang singkat dan akses data yang cepat.

Sistem informasi merupakan kombinasi teratur dari orang-orang, perangkat keras, perangkat lunak, jaringan komunikasi, dan sumber daya yang mengumpulkan, mengubah, dan menyebarkan informasi dalam sebuah organisasi. (Stair \& Reynolds, 2020). Kearsipan merupakan aktivitas penerimaan, pencatatan, penyimpanan, penggunaan, pemeliharaan, penyusutan, dan pemusnahan arsip. (Feng, 2017)

Oleh karena sebab itulah penggunaan sistem berbasis komputer sangat diperlukan untuk menampung data-data detail dari setiap organisasi yang mendaftarkan para pegawainya untuk mengikuti jaminan social tenaga kerja. Dengan memanfaatkan teknologi yang ada sangat memudahkan bagi organisasi khususnya Lembaga Jaminan Sosial untuk melakukan pengelolaan arsip berbasis digital yang memberikan kemudahan dan kecepatan dalam penyimpanan dan pengaksesan dari arsip yang ada dalam organisasi. Selain itu penggunaan teknologi informasi ini bisa memberikan solusi terbaik terkait permasalahan kearsipan yang selama ini penulis lihat dialami oleh Lembaga Jaminan Sosial dimana dengan sebuah sistem informasi yang memadai tentang kearsipan dapat memberikan jawaban dari kesulitan institusi dalam melakukan pengelolaan kearsipan di wilayah operasionalnya.

\section{METODE PENELITIAN}

Lokasi penelitian dilakukan di Lembaga jaminan social di wilayah Jawa Barat. Populasi dalam penelitian ini adalah pegawai tetap di Lembaga jaminan social tersebut yang berada pada bagian kearsipan dengan jumlah 52 orang. Data penelitian yang digunakan adalah data primer yaitu berupa kuesioner terkait dengan penggunaan system lama dan system baru yang diterapkan. 
Di dalam tahapan pengembangan sistem, ada beberapa tahap yang harus dilalui berdasarkan System Development Life Cycle (SDLC), yaitu perencanaan, analisis dan perancangan (Hevner \& Chatterjee, 2010).

\section{HASIL DAN PEMBAHASAN}

Kemajuan suatu organisasi memerlukan dukungan manajemen yang tepat. Untuk mengelola manajemen memerlukan data dan informasi. Salah satu sumber data adalah arsip, karena arsip adalah bukti dan rekaman kegiatan atau transaksi mulai dari kegiatan sampai akhir kegiatan yang berhubungan dengan pengambilan keputusan. Arsip- arsip tersebut digunakan baik untuk keperluan intern (penggunaan data dan informasi untuk keperluan internal kantor) maupun untuk keperluan ektern (pelayanan kepada masyarakat dan peserta).

Salah satu informasi yang sangat penting bagi suatu lembaga adalah rekaman dari kegiatan lembaga itu sendiri. Rekaman tersebut terdapat pada arsip. Data diolah menjadi informasi secara manual maupun komputer. Informasi digunakan untuk mengambil keputusan. Walaupun sudah dikelola oleh komputer, arsip harus tetap disimpan sebagai bahan bukti yang otentik. Di sinilah letak pentingnya Digitalisasi Arsip.

Pentingya pelaksanaan Digitalisasi Arsip juga bertujuan untuk meningkatkan proses pencarian arsip yang dibutuhkan. Demikian pula halnya Digitalisasi Arsip ini adalah salah satu upaya antisipasi terjadinya klaim ganda dari peserta Lembaga Jaminan Sosial.Berikut adalah pemberkasan yang dilakukan selama ini pada Lembaga jaminan social :

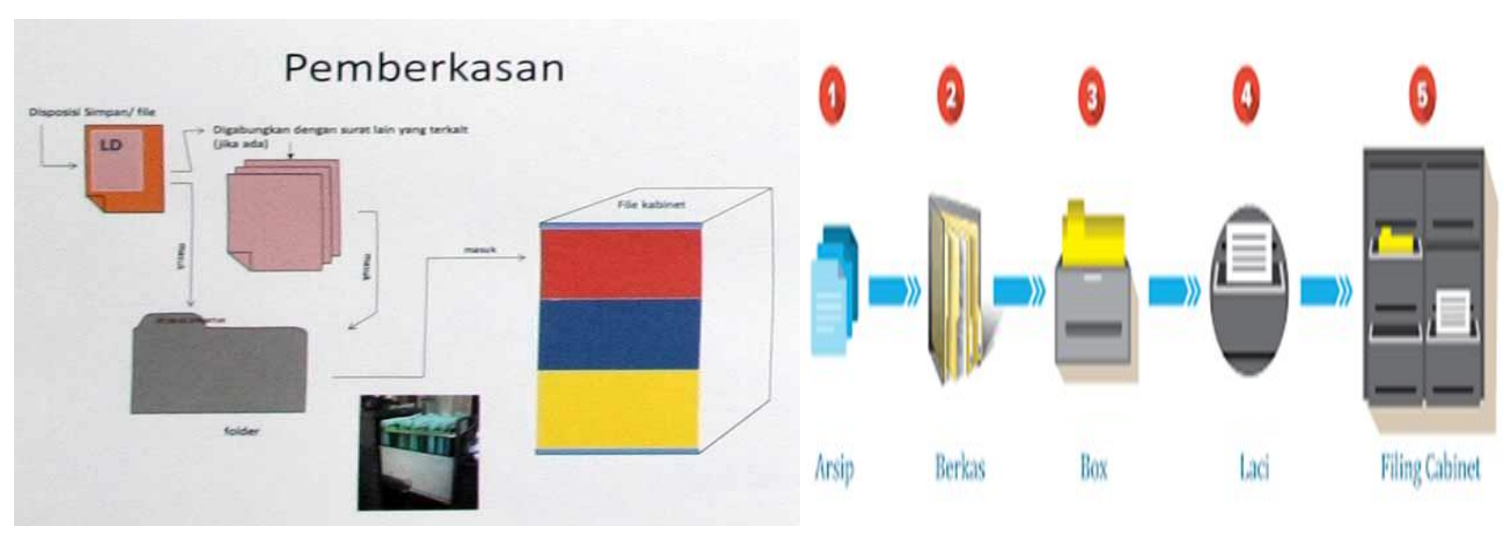

Gambar 1. Alur bagan

Dari gambar alur bagan terlihat bahwa dokumen yang masuk senantiasa diterima oleh admin adapun dokumen tersebut berupa data-data mitra kerjasama lembaga jaminan sosial yang memuat data-data penting seperti data karyawan dan lain sebagainya. Data yang diterima tersebut akan dilakukan pengecekan oleh admin 
April, 2021

dan jika sudah dinyatakan cukup dan sesuai maka dokumen tersebut akan disimpan di lemari khusus yang digunakan dalam menyimpan arsip-arsip perusahaan tersebut. Sistem yang digunakan lembaga jaminan sosial pada dasarnya masih bersifat konvensional sehingga ada kesan data yang digunakan lebih lambat dan kurang optimal dalam penyimpanan nya. Berikut beberapa masalah yang yang timbul dikantor bagian administrasi yaitu:

a. Pencatatan dokumen yang berasal dari mitra ataupun dokumen yang sifatnya internal masih dikerjakan secara manual dan menggunakan tulis tangan.

b. Ada beberapa dokumen yang penyimpanannya tidak sesuai dengan urutannya sehingga menyulitkan dalam proses pencarian.

c. Pengelolaan kearsipan membutuhkan proses waktu yang cukup lama untuk mengetahui arsip yang disimpan dan mengakses data-data yang disimpan.

d. Pegawai pada umumnya mengalami ksulitan dalam melakukan akses arsip yang dibutuhkan tidak jarang arsip yang dibutuhkan perlu waktu yang cukup lama untuk dapat di akses kembali karena metode pencarian yang cukup sulit dan dokumen yang banyak sehingga menyulitkan pegawai untuk mencari dokumen tersebut.

e. Serta ada beberapa dokumen yang rusak bahkan hilang ketika disimpan dalam lemari penyimpanan.

\section{Analisis sistem}

\section{Analisis Kebutuhan}

Analisa kebutuhan ini mencakup apa saja yang dibutuhkan agar sistem dapat berjalan secara optimal dan dapat maksimal saat digunakan adalah sebagai berikut:

a. Sistem yang dibuat pada dasarnya hanya merupakan sistem yang membantu dalam pengelolaan kearsipan yang ada di lembaga jaminan sosial.

b. Sistem yang dibuat digunakan untuk menyimpan data dan arsip lembaga secara digital melalui proses scan dan print.

c. Sistem yang digunakan dapat memudahkan pencarian atau akses kembali pada saat data tersebut diperlukan.

d. Program perancangan sistem management pengarsipan elektronik berbasis berbasih php dengan mysql sistem ini juga menggunakan sistem lan yang memungkinkan sitem berbagi file yang dan mengupload file yang penting.

\section{Analisis Kebutuhan Operasional}

Analisis kebutuhan ini mencangkup kebutuhan apa saja yang diperlukan dalam menjalankan system agar dapat berjalan optimal hal ini dipandang dari sudut pandang perangkat keras dan perangkat lunaknya berikut penulis utarakan: 
April, 2021

Kebutuhan system Perangkat Keras

1. Unit Komputer dengan sepsifikasi (Prosesor minimal Core i5 generasi ke 6 3,2 GHz, Ram 8 gb, Vga Ati radeon atau Nvidia 4Gb , Harddisk $5 \mathrm{~Tb}$ )

2. Scanner dengan tipe terbaru untuk hasil scan yang jernih

3. Printer untuk keperluan print out dari sistem yang digunakan

4. Monitor dengan resolusi full HD atau 1920 X 1080

5. Kebutuhan Software (Windows 10, Software XAMPP versi 1,9 keatas, Software Dreamweaver, Mysql)

Dari data analisis kebutuhan tersebut tidak bersifat tetap dan dapat berubah tergantung dari kebutuhan dan juga modernisasi sistem kedepan sehingga bila ada perubahan mekanisme sistem maka hardware dan software harus disesuaikan. Analisa kebutuhan ini mengacu pada penggunaan sistem agar dapat berjalan optimal dan sesuai harapan user.

\section{Fitur Utama Sistem}

Berikut kami sampaikan poin-poin yang diperlukan terkait Sistem Informasi Digitalisasi Arsip:

- Informasi Arsip: (Pengetahuan tentang Kearsipan, Informasi Terkini tentang Kearsipan Lembaga Jaminan Sosial, Konten Video Tutorial)

- Digitalisasi Arsip: (Import Database dari ELO Enterprise, Scanning dan Indexing Arsip)

- Pencarian Arsip: (Detail Arsip)

- Daftar Arsip: (Arsip Aktif, Arsip Inaktif)

- Katalog Arsip: (Denah Rak Arsip, Rekapitulasi Boks Arsip, Cetak Label Arsip)

- Peminjaman dan Permintaan Legal Arsip: (Peminjaman Arsip, Permintaan Legal Arsip, Reminder, Pengembalian Arsip)

Penyusutan Arsip: (Pemindahan Arsip, Usulan Pemindahan Arsip, Berita Acara Pemindahan Arsip)

Refresh Data: (Arsip Inaktif, Masa Retensi Arsip)

Pemusnahan Arsip: (Usulan Pemusnahan Arsip, Update Status Arsip, Berita Acara Pemusnahan Arsip)

- Daftar Pemusnahan Arsip

\section{Asumsi dan Dependensi}

Ruang lingkup fungsi digitalisasi arsip meliputi seluruh aspek kegiatan arsip Lembaga Jaminan Sosial terutama terkait dengan aspek Alih media arsip Lembaga Jaminan Sosial. Sistem Informasi Digitalisasi Arsip digunakan sesuai hak dan kewajiban karyawan Lembaga Jaminan Sosial yang berisikan materi mengenai Pengetahuan dan Informasi Arsip, Scanning dan Indexing Arsip, 
April, 2021

Pencarian Arsip, Daftar Arsip, Katalog Arsip, Peminjaman dan Permintaan Legal Arsip, Jadwal Retensi Arsip dan Penyusutan Arsip.

\section{Kekurangan Sistem Saat Ini:}

Saat ini aplikasi Digitalisasi Arsip masih menggunakan aplikasi ELO Enterprise yang perlu dilakukan pengembangan, yaitu Masih menggunakan Vendor (pihak ketiga), Masih bersifat local database (belum terpusat), Interface aplikasi belum user friendly dan Role user terbatas

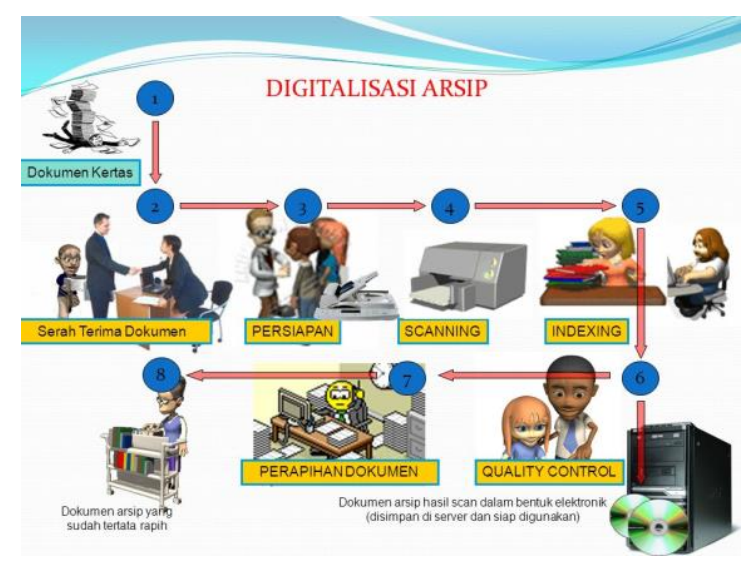

Gambar 2. Arsitek desain sistem

Desain sistem secara umum akan menggunakan sistem berbasis web, sistem yang akan diimplementasikan pada perangkat keras desktop yang dengan menggunakan software php dan mysql sebagai basis data yang akan digunakan sehingga sistem arsip yang saat ini digunakan secara konvensional dapat di konbersikan dengan baik dan efektif pada sebuah sistem berbasis komputer yang user friendly. Sistem ini juga membatasi otoritas user yang berhak menjalankan sistem tersebut jadi sistem ini tidak dapat diakses oleh semua pihak baik dalam kalangan internal perusahaan maupun dari pihak eksternal sistem dapat di akses oleh orang yang ditunjuk sebagai admin dalam penggunaan sistem tersebut yang kita sebut user admin.

\section{Perancangan database dan desain aplikasi}

Perancangan sistem sering disebut dengan istilah desain yang dapat dikatakan adalah sebagai upaya atau proses penciptaan obyek baru. Proses yang dilakukan dalam pembuatan sebuah desain dalam basis data bertujuan untuk mendukung sistem informasi dan kearsipan elektronik pada lembaga jaminan sosial. Tujuan dari desain Database yaitu untuk menentukan data-data yang dibutuhkan dalam sistem tersebut, sehingga informasi yang dirancang akan dapat terpenuhi dengan baik dan sesuai dengan harapan user. Sebagai pendukung perancangan sistem informasi, database Mysql digunakan sebagai media penyimpanan data dalam 
April, 2021

aplikasi pengolaan arsip digital pada lembaga jaminan sosial. Berikut rancangan dalam desain aplikasi yang akan penulis gunakan :

\section{Struktur database}

Strukture database merupakan rancangan data base yang akan digunakan dalam sistem yang akan diimplementasikan dalam strukture database ini akan melibatkan beberapa tabel data yang akan menampung informasi tentang data terkait seperti tabel mitra ,tabel dokumen dan tabel cari dokumen.

Tabel 1. mitra Lembaga Jaminan Sosial

\begin{tabular}{|l|l|l|l|}
\hline No & Nama Field & Tipe & Lebar \\
\hline 1 & ID_Mitra & Text & $\mathbf{3 0}$ \\
\hline 2 & Nama_perusahaan & Text & $\mathbf{5 0}$ \\
\hline 3 & Alamat & Text & $\mathbf{5 0}$ \\
\hline 4 & No_Telp & Text & 15 \\
\hline
\end{tabular}

Tabel mitra lembaga jaminan sosial ini digunakan untuk menginput data-data dokumen yang diserahkan oleh lembaga lain yang menjadi mitra dari lembaga jaminan sosial dengan adanya tabel ini diharapkan dapat mempermudah pengaksesan kembali dokumen yang diperlukan bila disandarkan pada kemitraannya dengan lembaga jaminan sosial. Tabel ini nantinya akan diisi oleh informasi seputar perusahaan mitra lembaga jaminan sosial yang sudah memberikan dokumen-dokumen nya ke lembaga jaminan sosial.

Tabel 2. Dokumen Detail

\begin{tabular}{|l|l|l|l|}
\hline No & Nama Field & Tipe & Lebar \\
\hline 1 & ID_Dokumen & Text & $\mathbf{3 0}$ \\
\hline $\mathbf{2}$ & Nama_Dokumen & Text & $\mathbf{5 0}$ \\
\hline $\mathbf{3}$ & Asal_Dokumen & Text & $\mathbf{5 0}$ \\
\hline 4 & Tgl_Dokumen & Text & 15 \\
\hline 5 & Deskripsi & Text & 1000 \\
\hline
\end{tabular}

Berdasarkan data tabel diatas dapat dijelaskan bahwa tabel dokumen detail akan memuat keseluruhan data-data yang diperlukan guna memudahkan dalam pencarian kembali dokumen yang tersimpan. ID_Dokumen merupakan kode unik yang digunakan untuk membedakan satu dokumen dengan dokumen lain sehingga tidak ada dokumen yang ganda hal ini akan memudahkan admin dalam pencarian dokumen nantinya. Nama dokumen memiliki fungsi memberikan penamaan terkait dengan dokumen yang di imput misalnya dokumen yang di inputkan adalah dokumen nama-nama pegawai yang terdaftar pada mitra lembaga jaminan sosial sehingga dengan begitu satu dokumen dengan dokumen lainnya dapat disesuaikan dengan metode alfabet yang lebih tersusun rapih. Asal dokumen ini menunjukan bahwa dokumen yang diterima berasal dari mana apakah dari sumber internal atau eksternal sehingga kalsifikasi dapat lebih mudah dilakukan. Terakhir tanggal dokumen memuat tanggal kapan dokumen itu diinputkan dengan begitu 
April, 2021

lembaga jaminan sosial akan dapat melihat database sesuai dengan tanggal yang tertera pada saat penginputan dokumen.

Tabel 3. Cari Dokumen

\begin{tabular}{|l|l|l|l|}
\hline No & Nama Field & Tipe & Lebar \\
\hline 1 & ID_Dokumen & Text & $\mathbf{3 0}$ \\
\hline $\mathbf{2}$ & ID_Mitra & Text & $\mathbf{5 0}$ \\
\hline $\mathbf{3}$ & Asal_Dokumen & Text & $\mathbf{5 0}$ \\
\hline 4 & Tgl_Dokumen_Masuk & Text & $\mathbf{1 5}$ \\
\hline $\mathbf{5}$ & Nama_Perusahaan & Text & $\mathbf{5 0}$ \\
\hline 6 & Nama_Dokumen & Text & $\mathbf{3 0}$ \\
\hline
\end{tabular}

Data tabel cari dokumen ini akan memuat informasi tentang dokumen yang akan diakses kembali setelah dokumen di inputkan hal ini digunakan untuk memudahkan admin dalam pencarian database yang sebelumnya cukup memakan waktu dalam proses pencarian. Untuk memudahkan pencarian maka dalam kolom database akan memunculkan ID_Dokumen dan ID_Mitra yang berfungsi untuk mencari dokumen yang sudah terinput berdasarkan kode unik yang diberikan sehingga pencarian dokumen akan dapat lebih baik dan lebih cepat juga efektif. Berikut tampilan awal form rancangan pengelolaan kearsipan lembaga jaminan sosial

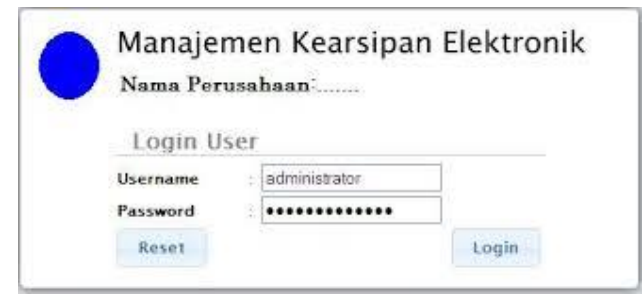

Gambar 3. Menu Login

Gambar 3 tersebut menunjukan gambar login yang akan digunakan oleh admin kearsipan dimana username dan password diberikan oleh bagian kepegawaian sesuai dengan jabatan dan juga posisinya dalam pengelolaan kearsipan sehingga admin pengelolaan kearsipan dibagian front office bisa berbeda dengan bagian pengelolaan kearsipan yang ada dalam back office hal ini dimaksudkan untuk menghindari fraud-fraud yang bisa saja terjadi dan sebagai sistem kontrol kearsipan yang dilakukan oleh manajemen sehingga antara kepala arsip dengan pegawai bagian kearsipan akan memiliki username dan pass masing-masing juga tampilan yang berbeda.

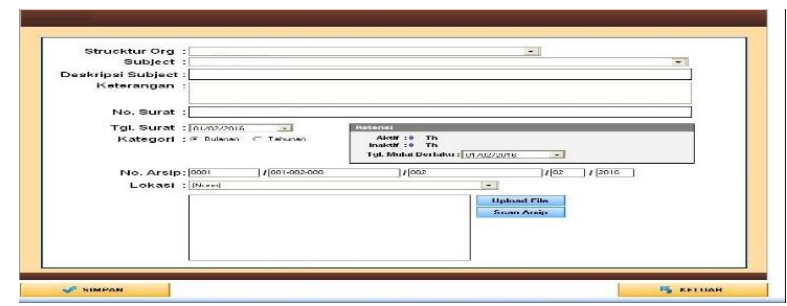

Gambar 4. Menu Input

Bisnis Dan Iptek | Sekolah Tinggi Ilmu Ekonomi Pasundan Bandung 
April, 2021

Pada gambar 4 merupakan gambar tampilan awal input data kearsipan dimana dalam form tersebut seorang admin akan mudah melakukan input dokumen dan memberikan keterangan sesuai dengan kebutuhan yang akan membantu memudahkan dalam pengelolaan juga akses kembali arsip yang dibutuhkan.

\section{Pengujian pemakaian sistem}

Merupakan suatu tahap yang sangat penting karena melakukan proses uji aplikasi sistem basis data yang akan di implementasikan, dan melakukan revisi jika sistem memiliki kekurangan-kekurangan serta memastikan bahwa sistems yang digunakan akan bebas dari kesalahan sebelum dilakukannya implementasi. Dari hasil program yang telah dirancang ini akan dilakukan proses uji sistem secara fungsional. Hasil pengujian dilakukan sebagai berikut pada table 4 dibawah ini:

Tabel 4. Pengujian Form

\begin{tabular}{|l|l|}
\hline Pengujian Form Arsip & $\begin{array}{l}\text { Admin menginput keterangan tentang } \\
\text { dokumen terkait }\end{array}$ \\
\hline Proses awal & $\begin{array}{l}\text { System akan memunculkan form input } \\
\text { data yang akan memberikan layanan } \\
\text { pada user untuk melakukan input data } \\
\text { sesuai dengan program yang } \\
\text { direncanakan form }\end{array}$ \\
\hline Hasil uji coba & $\begin{array}{l}\text { Data yang diinputkan melalui form } \\
\text { masuk kedalam table data yang ada } \\
\text { pada My sql sehingga data ter record } \\
\text { dengan sempurna dan }\end{array}$ \\
\hline Kesimpulan & $\begin{array}{l}\text { Data form input data dapat digunakan } \\
\text { sesuai dengan fungsinya dan } \\
\text { memudahkan admin dalam melakukan } \\
\text { proses penyimpanan. Diterima }\end{array}$ \\
\hline
\end{tabular}

Berdasarkan data hasil pengujian form input data dokumen maka hasil pengujian bahwa data dapat tersimpan dengan sempurna dan data dapat terinput melalui system sesuai dengan perancangan awal sehingga dapat disimpulkan metode input melalui form data ini dapat diterima dan layak untuk diimplementasikan. Setelah melakukan pengujian form maka akan dilanjutkan dengan pengujian pencarian data seperti yang digambarkan dalam table 5 dibawah ini:

Tabel 5. Pencarian Dokumen

\begin{tabular}{|l|l|}
\hline Pengujian Pencarian Dokumen & $\begin{array}{l}\text { Admin melakukan pencarian dokumen } \\
\text { yang akan digunakan yang sebelumnya } \\
\text { telah tersimpan }\end{array}$ \\
\hline Proses awal & $\begin{array}{l}\text { Admin memasukan ID_Dokumen dan } \\
\text { ID_Mitra yang sudah di inputkan }\end{array}$ \\
\hline Proses
\end{tabular}

Bisnis Dan Iptek | Sekolah Tinggi Ilmu Ekonomi Pasundan Bandung 


\begin{tabular}{|l|l|}
\hline & $\begin{array}{l}\text { sebelumnya maka system akan secara } \\
\text { lansgung mencari dokumen yang }\end{array}$ \\
dibutuhkan tersebut dengan mengacu \\
pada ID atau kode unik yang \\
dimunculkan oleh system secara \\
otomatis \\
\hline Hasil uji coba & $\begin{array}{l}\text { Data dokumen yang dibutuhkan akan } \\
\text { muncul dalam system berdasarkan } \\
\text { kategori Penomoran ID sehingga data } \\
\text { yang dicari dapat langsung terakses } \\
\text { tanpa harus mencari data-data lainnya }\end{array}$ \\
\hline Kesimpulan & $\begin{array}{l}\text { Metode pencarian dokumen dapat } \\
\text { berjalan sesuai dengan perancangan } \\
\text { system maka pencarian database ini } \\
\text { berhasil dilakukan dan dapat diterima } \\
\text { dalam proses implementasi system } \\
\text { nantinya }\end{array}$ \\
\hline
\end{tabular}

Berdasarkan data table 5 diatas dapat disimpulkan bahwa kondisi system ammpu menampilkan dokumen yang dibutuhkan dalam waktu yang relative cepat dan efektif sehingga admin tidak akan lagi kesulitan dalam mengakses kembali dokumen yang telah di simpan sebelumnya hal ini menunjukan bahwa system pencarian data memberikan kemudahan bagi admin dan juga dapat mempersingkat waktu pencarian dari system kobnvensional yang sebelumnya diterapkan.

\section{Bagan Alur Sistem}

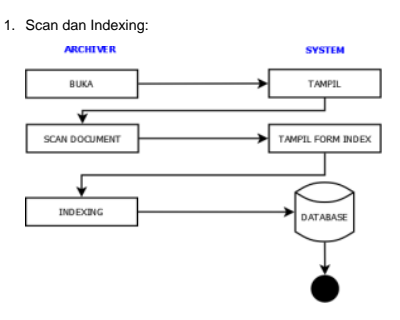

Gambar 5. Alur sistem

Dari data alur system diatas terlihat bahwa proses alur system yang pertama akan dipakai adalah scan dokumen proses scan dokumen ini adalah sebagai berikut :

1. Admin membuka login system

2. Maka system akan menampilkan menu menu scan dokumen

3. Proses scan dokumen dilakukan

4. Setelah dokumen terscan maka admin wajib mengentrikan data dan melakukan indexing terhadap dokumen yang sudah terscan tersebut dan mengklik selesai 
April, 2021

5. Dokumen yang terscan dan juga data-data yang di entrikan dalam form input data akan tersimpan atau terecord dalam database system.

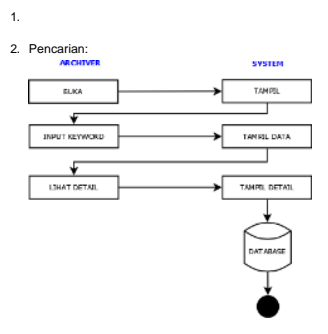

Gambar 6. Alur proses

Data alur sistem yang berikutnya adalah dalam proses pencarian dokumen berikut langkah-langkah yang akan dilakukan admin terkait dengan pencarian dokumen :

1. Admin membuka login sistem

2. Masuk kedalam sistem dan sistem akan menampilkan dokumen dokumen yang telah tersimpan sebelumnya berdasarkan alpabet dan juga berdasarkan ID_Dokumen

3. Admin dapat menggunakan form search dokumen dan memasukan kata kunci untuk mencari dokumen seperti Id dokumen atau Id mitra bisa juga nama dokumen yang diperlukan.

4. Maka sistem akan menampilkan dokumen sesuai dengan input keyword yang dimasukan sehingga admin dapat langsung melihat data dokumen yang dicarinya.

5. Dokumen yang dicari dapat ditampilkan secara detail dengan mengklik tampilkan dokumen secara detail sehingga sistem akan memunculkan dokumen secara lengkap juga dengan informasi data yang di input yang berkaitan dengan dokumen tersebut seperti nama dokumen,id dokumen asal dokumenntgl dokumen dll.

6. Tampilan detail akan disimpan dalam database untuk digunakan dilain waktu sehingga proses pencarian dokumen akan berjalan sangat cepat dan sangat efektif.

Peminjaman/Pemindahan/Pemusnahan:

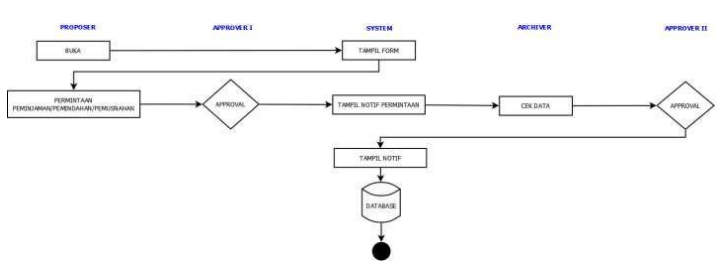

Gambar 7. Alur peminjaman 
April, 2021

Alur sistem yang ketiga adalah sistem peminjanan/pemindahan atau pemusnahan adapun langkah yang dilakukan adalah

1. User membuka aplikasi sistem dengan login sesuai dengan posisinya

2. Maka sistem akan tampilkan form secara detail terkait dengan dokumen yang tersimpan

3. User dapat melakukan permintaan terhadap sistem baik itu permintaan peminjaman pemindahan atau pemusnahan dokumen pada sistem tersebut

4. Maka sistem akan meneruskan permintaan tersebut pada pejabat yang terkait yang akan memutuskan apakah permintaan diterima atau ditolak

5. Maka pejabat yang berwenang akan menerima notif permintaan dari sistem terkait permintaan yang diminta tadi

6. Pejabat berwenang dapat mengecek data yang diminta secara detail sebelum memutuskan kebijakan apakah permintaan itu akan di pemunhi atau ditolak

7. Jika pejabat berwenang sudah melakukan pengecekan data maka keputusan akan diambil apakah data itu ditolak atau diterima

8. Maka user yang melakukan permintaan akan menerima notifikasi atrau jawaban dari pejabat yang berwenang terkait permintaan yang diusulkannya.

9. Maka sistem akan merecord kejadian tersebut dan akan menyimpannya dalam database sistem

\section{Pembahasan Penelitian Produk Akhir}

\section{Konsep pengelolaan sistem informasi kearsipan}

Konsep sistem pengelolaan informasi kearsipan yang sedang berjalan di Lembaga jaminan social saat ini, pada manajemen pengelolaan arsip saat ini masih menggunakan konsep konvensional adapun konsep digital namun masih melibatkan pihak ketiga sehingga kerahasiaan dokumen tidak terlalu terjaga. Dengan sistem yang pada umumnya masih mengandalkan cara konvensional ini pengelolaan kearsipan berjalan kurang efektif. Dengan penyusunan arsip menggunakan map dan filling cabinet di dalam lemari. Yang membutuhkan persedian tempat untuk peletakan lemari, filling cabinet, rak dan sebagainya sehingga pengelolaan kearsipan dirasakan kurang berjalan efektif.

\section{Permasalahan Yang Dihadapi Perusahaan Dalam Pengelolahan Arsip Dinamis}

Sistem pengolahan kearsipan di Lembaga jaminan sosial masih menggunakan sistem arsip konvesial dan digital yang belum berjalan optimal, dan untuk penyimpanan arsip dinamis menggunakan sitem digital yang masih melibatkan pihak ketiga dan local database. Sehingga membutuhkan waktu yang lebih lama dan kemungkinan data yang tidak akurat. Berikut uraian yang digunakan peneiti 
April, 2021

untuk menemukan permasalahan apa saja yang terjadi dalam kantor bagian administrasi:

1. Identifikasi masalah langkah awal dalam deskripsikan data, dengan melakukan identifikasi masalah bertujuan untuk mengevaluasi permasalahan dan hambatan yang terjadi.

2. Menganalisis sistem mengnalisis sistem dari kebutuhan yang diharapkan. Sehingga dapat diusulkannya perbaikan-pebaikan guna menunjang peningkatan sistem kearsipan menjadi lebih baik.

\section{Aplikasi Perancangan Sistem Informasi Manajemen Pengelolaan Arsip Digital Di Lembaga Jaminan Sosial.}

Rancangan sistem informasi manajemen earsip dinamis yang berbasis php dan Mysql. Dari hasil perancangan sistem yang ada dan sudah dijelaskan pada sub bab diatas perencanaan sistem ini akan digunakan sebagai alternative untuk memecahkan masalah yang ada di Lembaga jaminan sosial. Maka dari itu penulis melakukan perancangan kearsipan yaitu dengan menggunakan PHP dan Mysql sebagai aplikasi untuk merubah arsip yang tadinya berifat konvensial dan digital yang masih berorientasi pada pihak ketiga menjadi sistem kearsipan instansi yang dapat dikelola sendiri dan merubah arsip konvensional menjadi arsip elektronik guna untuk mempermudah dalam pengolaan kearsipan serta untuk mempermudah dalam mengetahui informasi data kearsipan di Lembaga jaminan social yang ada saat ini. Dan arsip yang telah diolah dapat tersimpan rapi dalam program database yang baik dan benar. Berikut beberapa rancangan dalam desain aplikasi yang akan dibuat.

Struktur tabel database Pembuatan aplikasi database pengarsipan Lembaga jaminan social ini yang terdiri dari: Tabel Dokumen, table pencarian dokumen dan table peminjaman, pemindahan dan pemusnahan dokumen. Query Hubungan yang terjadi pada suatu tabel dengan tabel yang lainnya, yang fungsinya bertujuan untuk mengatur operasi database. Perancangan query ditampilkan berdasarkan tabel yang telah dibuat dan dijadikan sebagai sumber data untuk mendesain form dan report dalam sistem informasi manajemen pengelolaan kearsipan di Lembaga jaminan social ini. Form yang dirancang sesuai kebutuhan perusahaan. Tampilan perancangan form di desain berdasarkan data table dan juga dibuat user friendly sehingga mudah untuk digunakan bagi user.

\section{KESIMPULAN}

Kesimpulan berdasarkan hasil dari analisis perancangan dan pengujian maka dapat disimpulkan bahwa sistem informasi manajemen pengelolaan kearsipan yang berbasis computer pada Lembaga jaminan sosial, dan memiliki basis data 
April, 2021

(database). Diharapkan dapat menyelesaikan masalah-masalah yang dialami yang terkait dengan kearsipan di Lembaga jaminan sosial. Aplikasi perangkat lunak PHP dan Mysql dapat dijadikan sebuah software alternative yang dapat digunakan dalam perancangan sistem pengelolaan kearsipan. Dengan adanya basis data (database) pada sistem informasi manajemen pengelolaan kearsipan dengan komputer dan menggunakan Mysql, mempermudah pencarian dokumen yang dibutuhkan. Report dan laporan yang dibuat sesuai berbasis PHP yang telah dibuat dan diformat dengan mudah, cepat dan akurat.serta efektif dalam mencari dokumen-dokumen yang sudah tersimpan cukup lama.

Adapun beberapa saran yang penulis harapkan agar dapat membantu perusahaan dalam meningkatkan efisiensi dan efektifitas yaitu perancangan sistem yang sudah dilakukan saat ini masih belum sepenuhnya sempurna maka perlu ada upaya terus menerus dalam menyempurnakan sistem sesuai dengan kebutuhan dan tantangan jaman. Perancang sistem informasi pengelolaa kearsipan yang penulis susun saat ini masih dikatakan sangat sederhana, untuk pengembangan selanjutnya diharapkan para peneliti lainnya dapat membuat perancangan yang lebih inovatif dan kreatif yang lebih memudahkan lagi dalam melakukan pengelolaan kearsipan. Untuk pihak kantor bagian administrasi gar dapat melakukan perawatan pada sistem informasi manajemen pengelolaan kearsipan baik dari segi software dan hardware agar sistem dapat bekerja dengan baik dan dapat terus beroperasi secara optimal serta tidak menimbulkan pengeluaran biaya yang besar dikemudian hari. Kemajuan teknologi yang begitu pesat harus dapat terimplementasi dalam sistem yang ada sehingga dalam prosesnya sistem ini akan terus sesuai dengan tuntutan jaman dan kebutuhan organisasi yang akan semakin besar.

\section{REFERENSI}

Barros, A., de Toledo Carneiro, A., \& Wanderley, S. (2019). Organizational archives and historical narratives: Practicing reflexivity in (re) constructing the past from memories and silences. Qualitative Research in Organizations and Management: An International Journal, 14 (3), 280294. https://doi.org/10.1108/QROM-01-2018-1604

Eveleigh, A. (2017). Participatory archives. Currents of archival thinking, 2, 299326.

Feng, H. (2017). Identity and archives: return and expansion of the social value of archives. Archival Science, 17(2), 97-112.

Hevner, A., \& Chatterjee, S. (2010). Design science research in information systems. In Design research in information systems (pp. 9-22). Springer, Boston, MA.

Bisnis Dan Iptek | Sekolah Tinggi Ilmu Ekonomi Pasundan Bandung 
Stair, R., \& Reynolds, G. (2020). Principles of information systems. Cengage Learning. 